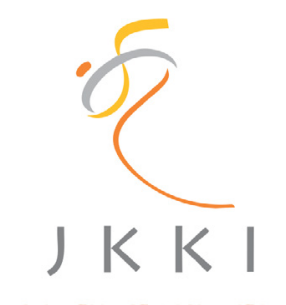

Jurnal Kedokteran dan Kesehatan Indonesia

Indonesian Journal of Medicine and Health

Journal homepage : www.journal.uii.ac.id/index.php/JKKI

\title{
Irritant contact dermatitis caused by sap of Rengas
}

Betty Ekawati Suryaningsih*1

${ }^{1}$ Department of Skin Health and Dermatology, Faculty of Medicine, Islamic University of Indonesia, Yogyakarta, Indonesia

Case Report

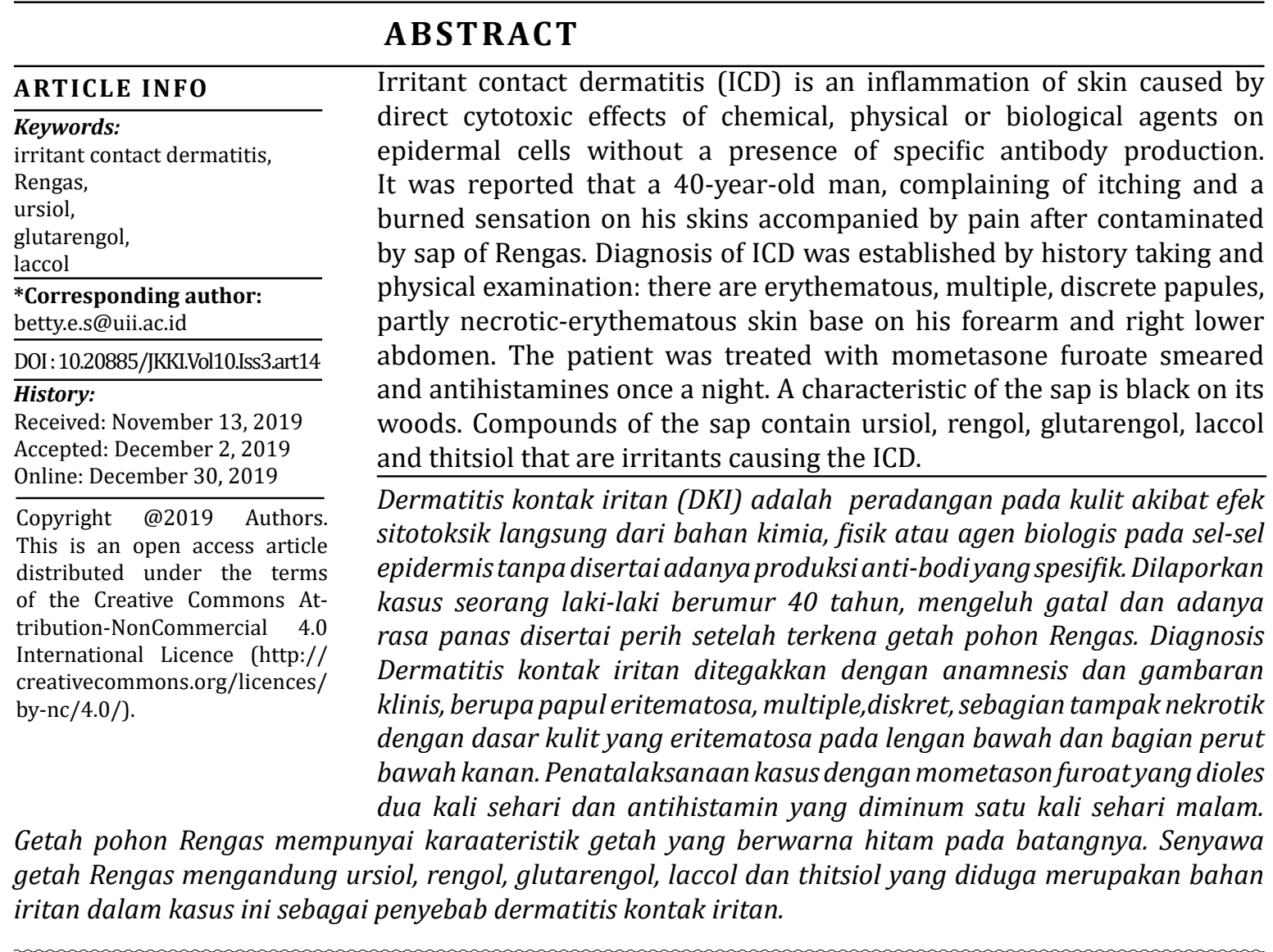

\section{INTRODUCTION}

Irritant contant dermatitis (ICD) is an inflammation of skin caused by direct cytotoxic effects of chemical, physical or biological agents on epidermal cells without a presence of specific antibody production. ${ }^{1}$ Exposure types of the ICD can be chemical, physical and biological agents. The ICD can be caused by endogen and exogen factors. Endogen factors causing the ICD may be gen, sex, age and atopic; meanwhile, exogen factors may be chemical irritants, mechanism (friction and pressure), environment (temperature and humidity) and radiation (ultraviolet). ${ }^{1,2}$

Rengas (Gluta Renghas L.) is a wood plant in Indonesia and the best productive wood. However, sap of the Renghas is known to have poison that can cause strong irritation 
to skins. It contains substances like ursiol, rengol, glutarengil, laccol and thisiol. ${ }^{3}$ It was reported that the sap, a rarely reported case, might cause the ICD. A diagnosis of a case was conducted based on a history taking and physical examination.

\section{CASE REPORT}

A 40 years old man, an entrepreneur, visited a clinic and complained about his itching and painful skins of his right hand and stomach. Based on a history taking, the itching and a florid of his hand had appeared since 5 days before. The itching was felt after he leaned on a big tree after sharing work (in Javanese, it is called gotong royong) of his village. He did not know a name of the tree, but he remembered that it had

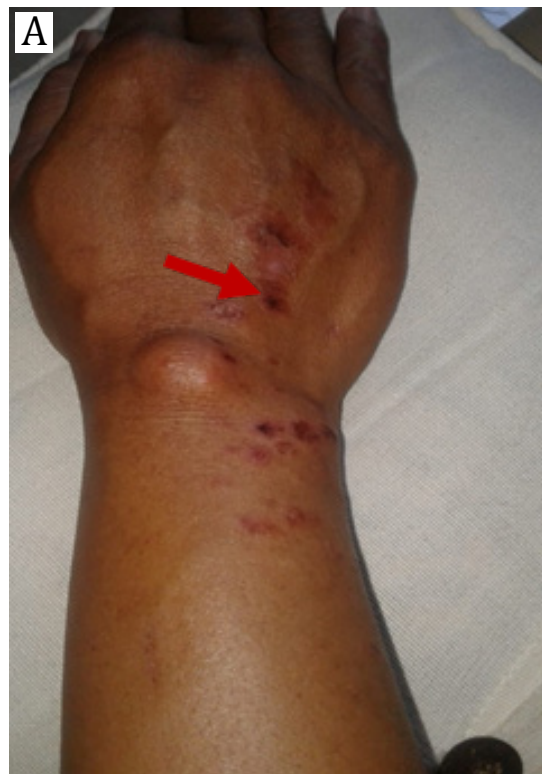

Figure 1. Condition of the patient's skin. The red cursor indicated an erythematous papule with necrosis on its top. The black cursor indicated erosion.

Based on both examinations, history taking and physical examination, the ICD might be caused by the sap of Rengas. The patient then were treated by metil prednisolone $16 \mathrm{mg} /$ day (16-0-0), cetirizine $1 \times 10 \mathrm{mg} /$ day and dermovel cream ${ }^{\circledR}$ smeared twice a day. He then revisited the clinic to control his skin. Unfortunately, his skin became better, so a path test was not conducted.

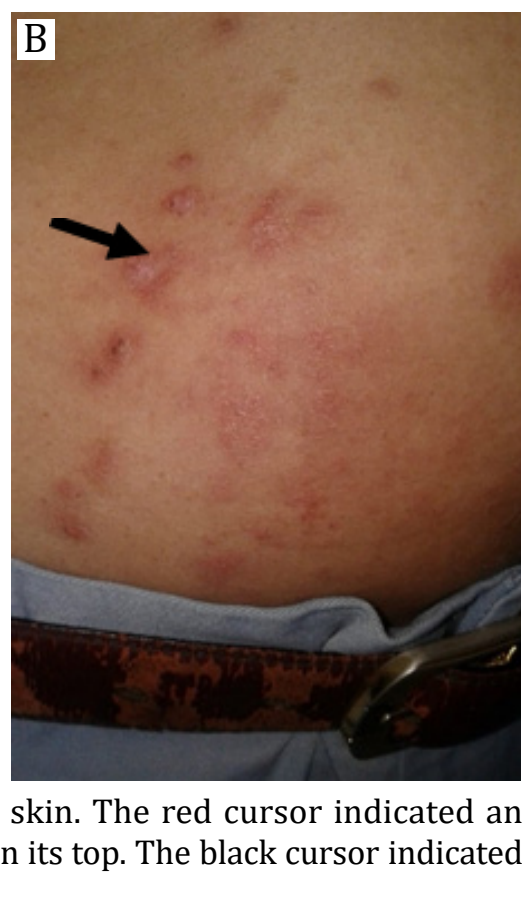

black sap. According to people of his village, it was known as Rengas. After affected by the sap, he washed his skins contaminated with the sap and gave eucalyptus oil on his skins. In fact, it could not cure it and even made his skins more itching and painful. In addition, he could not sleep well. Thus, he visited one of the skin care clinic in Yogyakarta to cure his skins.

Based on physical examination, generally he was compos mentis, normal vital signs, good nutritional status and normal swollen lymph nodes. At the right hand and lower abdomen, multiple papules with necrosis on their top, some appeared erosion with an erythematous skin base, were found. Physical condition of the skin can be seen in Picture 1 .

\section{DISCUSSION}

The Rengas tree is a tree included in a family of Anacardiaceous, and it is a source of a good wood in Indonesia. It is known by its poisonous sap that can cause strong irritation to skins and paralysis for a human..$^{2-4}$ It grows in primary forests, peat swamps, coast areas, riversides, and lowland forests to the hills. It can be found in Malaya, Sumatera, Jawa, Kalimantan and 
Sulawesi. Based on a literary review, a research on the tree needs go further.

The characteristics of the tree are reddish, stripped and not weathered. Its sap is deep black like liquid asphalt and contains substances like ursiol, rengol, glutarengol, laccol dan thitsiol. If the sap gets onto skins, it can cause strong irritation, itching, burned sensation and even peeling of skins. ${ }^{2,3}$ A substance of the sap usually affecting the irritation is urisol. Effects of other substances of the sap like glutarenghol have not been known yet. ${ }^{3,6}$ In this case, the patient got itching after leaning on a tree with a black sap and a red-stripped log, the Rengas.

The ICD is non-immunologic inflammation that happens because of kontaktan through eksogen and endogen. Endogen factors causing the ICD may be gen, atopic, ethnic, sex and age. Meanwhile, exogen factors causing the ICD may be irritant chemistry, exposure characteristics, environmental factors, mechanical factors and ultra violet (UV) radiation. The irritant chemistry consists of $\mathrm{pH}$, concentration, size, carrier and solubility; the exposure characteristics are numbers, time of exposure, concentration and types of kontaktan; the environmental factors are humidity, temperature and pressure; the mechanical factors affect the ICD because of substances in the tree. ${ }^{4-6}$

One of substances of the Rengas is ursiol suspected to be an immunogenic cell that triggers T cells and macrophages leading to hypersensitivity reactions of type IV. ${ }^{7}$ The sap of the Rengas can cause strong irritation, so in Malaysia it is not allowed to camp near the Rengas. Also, If contaminated with the sap, Malaysia educates its society how treat in the first actions to by washing contaminated skins with soap or water to avoid strong irritation. Some effects of the sap can be bullae, ulcers, fever and constitutional symptoms. ${ }^{1,8}$ A study of the Rengas, especially on how its leaves affected skins, was conducted by Lin and Whittow. In the study, a young steam of the Rengas was rubbed on an arm for 10 seconds. In fact, it caused serious effects on the skin as irritations caused by the Rengas lasted for 3 weeks and needed a clinical help. ${ }^{3}$

Clinically the ICD is classified into acute ICD and chronic ICD. The acute ICD appears because of exposures of acid chemical compounds or physical contacts. It usually happens because of work accidents. Effects of the acute ICD on the skins can be erythema, edema, vesicles accompanied by exudation, bullae formation and necrosis tissues in severe cases. The chronic ICD is caused by accumulation of repeatedly low irritant contacts causing some symptoms like dry skin, erythema, squama and lichenification. ${ }^{1,9}$

In this case, based on the history taking the patient felt pain, burned sensation and itching after contaminated by the sap of the Rengas. Dermatological examination of his skins showed erythema papules that some appeared necrotic with erythema on skin base. It could be concluded that he experienced the acute ICD because of the sap of the Rengas. His skin got better after treated by systemic and steroid topical smeared twice a day for three days. Also, administering antihistamine was treated once a day in the night. The antihistamine, a symptomatic treatment, was to reduce the itching symptoms. Then the steroid topical was to reduce reaction of ecematous inflammation, meanwhile the systemic topical was to heal his skin sooner because he experienced the acute ICD with medium intenseness.

\section{CONCLUSION}

Diagnosis of the ICD can be conducted based on an accurate history taking and physical examination. The acute ICD of the patient caused by the Rengas could be seen from the characteristics of the tree that is long and has black sap.

\section{CONFLICT OF INTEREST}

None declare.

\section{ACKNOWLEDGEMENT}

None declare.

\section{REFERENCES}

1. Amado A, Taylor JS, Sood A. Irritan con- 
tact dermatitis. In: Freedberg IM, Eisen AZ, Wolff K, Austen KF, Goldsmith LA, Katz SI (eds). Fitzpatrick's Dermatology in General Medicine. $7^{\text {th }}$ ed. USA.McGraw Hill. 2008. pp: 395-401.

2. G Xavier, KY Yong, M Pubalan. The wrath of the Rengas: A report of severe contact dermatitis and implication for public health in rural areas. Malaysian Journal of Dermatology.2016; 37: 41-43

3. Aziz D E. Studi Sitoktoksis Ekstarak Daun Rengas (Gluta Rengas L) sebagai Anti Bakteri. Skripsi Sarjana Fakultas MIPA Universitas Andalas.2017.

4. Asikin S. Flora Rawa Sebagai Pengendali Hama dan Penyakit Tanaman Syaiful Asikin. In: PEI proceeding. 2010. https://peibandung.files.wordpress.com/2010/10/prosiding-seminar-nasional-pei-2011.pdf

5. Dahl A, Strandhede S, Wihl J. Ragweed-an allergy risk in Sweden? Journal Aerobiologia. 1999; 15: 293-297.

6. Ducombs G and Schmidt RJ. Plants and plant product. In : Textbook of Contact Dermatitis. Springer. pp: 883-923

7. Kalcrgis AM, Lopez CB, Becker MI, et al. Modulation of Fatty Acid Oxidation Alters Contact Hypersensitivity to Urushiols: Role of Aliphatic Chain f3-0xidation in Processing and Activation of Urushiols. Journal Investigative Dermatology. 1997; 108(1): 57-61.

8. Kalish RS dan Wood JA. Induction of Hapten-Specific Tolerance of Human CD8+ Urushiol (Poison Ivy)-Reactive T Lymphocytes. Journal Investigative Dermatology. 1997; 108(1): 253-257.

9. Tumbuhan Beracun Di Malaysia Malaysia Camping Online. Diakses 6 Nov 2019 http://camping-malaysia.blogspot. com/2009/07/tumbuhan-beracun-di-malaysia. 